\title{
IN THE WAKE OF THE FLOOD: "LIKE PRODUCTS" AND CULTURAL PRODUCTS AFTER THE WORLD TRADE ORGANIZATION'S DECISION IN CANADA CERTAIN MEASURES CONCERNING PERIODICALS
}

\author{
RICHARD L. MATHENY, III ${ }^{\dagger}$
}

A commodity is therefore a mysterious thing, simply because in it the social character of men's labour appears to them as an objective character stamped upon the product of that labour....

[W] hat we have been calling postmodernism is inseparable from, and unthinkable without the hypothesis of, some fundamental mutation of the sphere of culture in the world of late capitalism, which includes a momentous modification of its social function....

What we must now ask ourselves is whether it is not precisely this semiautonomy of the cultural sphere which has been destroyed by the logic of late capitalism. ${ }^{2}$

\section{INTRODUCTION}

In Canada Certain Measures Concerning Periodicals, ${ }^{3}$ the panel ("Panel") and appellate body ("AB") of the World Trade Organization ("WTO") concluded that a Canadian excise tax on a certain type of periodi-

† B.A. 1991, Duke University; M.A. 1996, University of California, San Diego; J.D. Candidate 1999, University of Pennsylvania. I would like to thank the literature departments in Durham and La Jolla for positions deeply implicit in this Comment. To Robert Fitzgerald, Vivienne LaBorde, Lori Marino, and all of the associate editors at the University of Pennsylvania Law Review, I am indebted for their hard work and commitment. And I dedicate this Comment to my wife Lynn, who knows best the costs of its production, and because her love is so pure and selfless.

1 KARL MARX, CAPITAL 72 (Frederick Engels ed., Samuel Moore \& Edward Aveling trans., International Publishers 1967) (1867).

${ }^{2}$ FREDRIC JAMESON, POSTMODERNiSM, OR, THE CULTURAL LOGIC OF LATE CAPITALISM 47-48 (1991).

3 World Trade Organization Report of the Appellate Body, Canada Certain Measures Concerning Periodicals, June 30, 1997, available in 1997 WL 398913 [hereinafter Periodicals AB Report]; World Trade Organization Report of the Panel, Canada Certain Measures Concerning Periodicals, Mar. 14, 1997, available in 1997 WL 371097 [hereinafter Periodicals Panel Report]. The combined Panel and AB Reports will hereinafter be referred to collectively as Periodicals. 
cal was inconsistent with Canada's obligations under the General Agreement on Tariffs and Trade ("GATT"). ${ }^{4}$ Like a well-placed sandbag in an elaborate levee of cultural legislation, the excise tax had been enacted to shore up Canada's defenses against the broadening northward flow of U.S. mass culture. In the aftermath of the decision, many predict that the Canadian periodical market will indeed be flooded, ${ }^{5}$ as U.S.-produced magazines follow the example set by Sports Illustrated Canada, whose appearance on Canadian newsstands in 1993 rekindled this long-standing dispute. ${ }^{6}$

The dispute, which dates back as far as the $1920 \mathrm{~s},{ }^{7}$ centers on what one commentator has termed Canada's "most unambiguously protective cultural legislation."8 Responding to political pressures from an outraged national intelligentsia and a beleaguered Canadian publishing industry, the Canadian government has enacted legislation that aims to preserve Canada's cultural identity. ${ }^{9}$ More recently, the Canadian government successfully negotiated the "cultural industries" exemption from the Free Trade Agreement it entered into with the United States and Mexico. ${ }^{10}$ Because the United States wisely pursued the magazine complaint through the WTO, however, the controlling law was the GATT and not the NAFTA. ${ }^{11}$ Thus, Canada was

${ }^{4}$ General Agreement on Tariffs and Trade, Apr. 15, 1994, in GATT Secretariat, The Results of the Uruguay Round of Multilateral Trade Negotiations 21, GATT Sales No. 1994-4, art. III, II 2 (1994) (representing the trade agreement between 124 governments and the European communities who participated in trade negotiations held in April 1994) [hereinafter GATT].

${ }^{5}$ See infra notes 53-60 and accompanying text (describing the impact of the GATT on the Canadian periodical industry as a result of the allowance of split-run magazines).

${ }^{6}$ See John Schofield, Publish or Perish, Maclean's, June 2, 1997, at 44, 45 (noting the dissent caused by the introduction of a split-run edition of Sports Illustrated in 1993).

${ }^{7}$ See infra notes 43-49 and accompanying text (describing the conflict created by the success of U.S. periodicals in Canada).

${ }^{8}$ John Herd Thompson, Canada's Quest for Cultural Sovereignty: Protection, Promotion, and Popular Culture, in NORTH AMERICA WITHOUT BORDERS? 269, 272 (Stephen J. Randall et al. eds., 1992).

${ }^{9}$ See Anthony de Fazekas, Free Trade and Culture: An Alternative Approach, 2 DAIHOUSIE J. LEGAL STUD. 141, 154-55 (1993) (noting that the Canadian government relied on revenue sources, subsidies, content quotas, investment reviews, distribution bills, and procurement policies "to encourage the development of Canadian cultural industries").

${ }^{10}$ See North American Free Trade Agreement, Dec. 17, 1992, art. 2106, 32 I.L.M. 7a (1993) [hereinafter NAFTA]. Article 2106 carried forward Article 2005 of the Canadian Free Trade Agreement, which exempted the "cultural industries" from various obligations imposed by that treaty.

${ }^{11}$ Roy MacSkimming, the policy director for the Association of Canadian Publishers called the U.S. forum shopping an "aggressive, hostile" act, that calls into question the good faith of the United States in negotiations concerning cultural exemptions with Canada. Canadian Officials Claim Unanimity on Preserving Cultural Protections, N. AM. FREE TRADE \& INVESTMENT REP., Feb. 28, 1997, available in 1997 WL 9049769, at *7 [hereinafter Canadian Officials]. It remains an open question what other concessions negotiated in the NAFTA 
left holding a worthless note in the NAFTA exemptions, which seems to have evaporated under the WTO trading regime.

In the Periodicals case, the Appellate Body of the WTO affirmed the Panel's finding of a violation of Canada's obligations under Article III of the GATT. Article III provides for national treatment of the imported good, requiring a GATT member ("Member") to treat goods imported from another Member just as it treats similar, or "like," domestic goods." "Thus, Article III seeks to eliminate any discriminatory internal taxes imposed by a Member nation on the goods imported from another Member nation. Among the discriminatory internal taxes found to violate Article III was an eighty percent excise tax on a certain type of magazine called a "splitrun."13

The litigation of this dispute featured a U.S. campaign to define the GATT's national treatment obligations broadly so as to encourage international competition, contrasted with the Canadian argument that magazines be distinguished by their content-a position fundamental to Canada's array of cultural legislation. By all accounts, the Canadian government in Periodicals has suffered a great blow to its authority to legislate safeguards for its cultural industries. The Periodicals case could be disastrous in the short term for domestic magazine producers who, despite the benefits of the Canadian "cultural legislation," have clung tenuously to an $18.6 \%$ market share of English language publications. ${ }^{14}$ If, as many predict, the WTO's Article III interpretation in Periodicals throws open the floodgates that were vital to the Canadian magazine industry's tenability, ${ }^{15}$ then the Periodicals case seems an appropriate place from which to consider the various tensions between the globalization of free trade and the cultural industry, sovereignty, and identity of nations participating in that trade. As China contemplates membership in the GATT, and the WTO embraces both larger regions and more diverse sectors of a global economy, the issues raised in Periodicals are of unquestionable significance. This Comment anticipates

are similarly circumventable through the WTO; however, since the relevant parts of GATT Article III have undergone no major revision since their drafting, Canada was arguably on notice as to these issues when it initially negotiated the NAFTA exemptions.

12 GATT, art. III, I 4 (stating that such products "shall be accorded treatment no less favorable than that accorded to like products of national origin").

${ }^{13}$ See infra note 52 and accompanying text (providing a definition of "split-run").

14 Periodicals Panel Report, supra note 3, I 3.29 (stating that "foreign magazines dominate the Canadian market ... [at] 81.4 percent of all newsstand circulation").

15 See Robin L. Van Harpen, Mamas, Don't Let Your Babies Grow Up to Be Cowboys: Reconciling Trade and Cultural Independence, 4 MINN. J. GlOBAL TRADE 165, 173-74 (1995) (predicting that a three percent shift in advertising revenue from Canadian- to U.S.produced magazines would be fatal to the Canadian magazine industry). 
that they will be posed again, in other contexts, ${ }^{16}$ before panels of a different composition, adjudicating the relationship between goods (and services) of a distinct character.

Part I opens with an introduction to the WTO and Article III of the GATT. A short history of the "like products" clause, including the factors relevant to a "like products" inquiry, helps to establish the legal framework in which the Periodicals dispute developed.

Part II places the dispute in its historical context. After reviewing the success of U.S. cultural production on the Canadian markets, Part II examines the Canadian government's legislation in the area of domestic cultural industries. Part II also considers the historically novel qualities of the satellite-transmitted split-run magazine, which allowed Time Warner to circumvent the Canadian legislation.

Part III analyzes the litigation of this case at both the panel and appellate levels, with particular attention given to issues arising under Article III, paragraph 2 of the GATT. The analysis will focus on some of the interpretive tensions in Article III, paragraph 2 as a means of understanding how this provision is currently handled by the WTO.

Finally, Part IV attempts to assemble from Periodicals a vocabulary of trade-related concepts about culture. These concepts are used to discuss the case as symptomatic of a deeper contradiction between globalized trade in products and cultural identities that depend to some degree on those products for their expression and maintenance. Magazines, and similar cultural products, are hybrid in character: their content is a public good, but they are delivered to consumers in private-good form. ${ }^{17}$ When hybrid cultural products are subjected to GATT obligations, the result is a negative externality - the underproduction of that product - the remedy of which is not easily reconciled with the logic of the free market. This Comment argues for an amendment to Article III of the GATT-or, alternatively, a different interpretation of the current Article III-to ensure that domestic legislation re-

${ }^{16}$ Some suggest that the U.S. victory in Periodicals will lead to import pressure on other Canadian markets, such as the distribution of feature films and television signals. See Canadian Officials, supra note 11, at *4 ("International Trade Minister] Eggleton suggested that the success of the WTO challenge on periodicals ... could lead to pressure in other areas ...."); see also Marci McDonald, A Blow to Magazines, MACLEAN's, Jan. 27, 1997, at 58, 58 (stating that trade experts see the WTO's Periodicals ruling "as a precedent for U.S. challenges to [Canada's] other beleaguered cultural industries, from book publishing to broadcasting").

${ }^{17}$ See infra notes 128-33 and accompanying text (discussing the concept of magazines as public goods). 
garding cultural products is sheltered by a comprehensive "like products" analysis.

\section{THE WORLD TRADE ORGANIZATION AND ARTICLE III}

\section{A. The World Trade Organization}

The victorious allied nations negotiated the GATT following World War II, and, since 1947, the GATT has served as the "centerpiece of the international economic law system." 18 In this capacity, the GATT sets forth the obligations of Member nations with respect to the products of other Member nations with the general purpose of eliminating barriers to trade. In an effort to better adjudicate disputes arising from this system, GATT Member nations fashioned and signed into existence the WTO on April 15, 1994 as part of the "Uruguay Round Agreements." In simple form, the WTO is composed of three-person panels and a standing appellate body of seven. The panels hear disputes and suggest resolutions, while the appellate body takes appeals on "issues of law covered in the panel report and legal interpretations developed by the panel,", and can uphold, modify, or reverse conclusions made by the panel. ${ }^{20}$ International trade disputes arising under the GATT are litigated to a conclusion within this framework, which resembles a judicial body. 21

\section{B. Article III: The National Treatment Provision}

The dispute litigated in Periodicals arose under GATT Article III, which generally guarantees that imported products receive national treatment in the importing market; that is, that the imported product will face no discriminatory taxes in the importing nation. Of course, the globalization of trade brings a great variety of products into competition with one another. The classification of these products for the purpose of trade regulation is an

${ }^{18}$ Curtis Reitz, Enforcement of the General Agreement on Tariffs and Trade, 17 U. PA. J. INT'L ECON. L. 555, 555 (1996).

19 See id. at 556-57 \& n.4 (noting the creation of the WTO after seven years of effort).

${ }^{20}$ See id. at 580-84 (quoting Understanding on Rules and Procedures Governing the Settlement of Disputes, GATT, Annex 2, art. 17, I 6, 33 I.L.M. at 1236) (describing the WTO panels and appellate body).

21 See id. at 583 (discussing similarities between the WTO and judicial bodies). There are, however, important differences, some of which play a role in the Periodicals dispute. For instance, the precedential weight of panel appellate body reports is an open question, as is the authority of the appellate body to resolve issues not litigated before the panel. On this latter point, see infra notes 87-90 and accompanying text (discussing problems encountered by the Panel when it tried to analyze hypothetical situations). 
exercise in determining the competitive relationships that ought to exist between them, and constitutes, therefore, a political act of enormous economic consequence. The beneficial economic effects of trade liberalization can be registered with empirical clarity (indeed, the effects are even susceptible to accurate prediction, which is then rightly used to justify legislation). Regrettably, it is only in hindsight that the social and cultural after-affects of trade agreements are sought to be understood. In Part III, this Comment will examine more comprehensively the doctrinal mechanics of Article III in an effort to explain this marginalization of non-economic interests. In summary, however, the key issue under Article III is whether the domestic good and the differently taxed imported good are "like products."

Because a finding of "likeness" among domestic and imported products requires the importing Member to afford national treatment to the product seeking entry, the concept is of no small consequence. Indeed, Article IIIperhaps to a greater degree than any other article of the GATT - challenges national legislative sovereignty by calling into question the legality under the GATT of domestic policies and provisions. ${ }^{22}$

\section{The History of "Like Products"}

Past GATT panels have deliberated about the "likeness" of many different products, considering the qualities of, for instance, unroasted coffees, ${ }^{23}$ tuna catches, ${ }^{24}$ and alcoholic beverages of various types. ${ }^{25}$ Periodicals proposes to answer the question whether domestic and imported splitrun magazines are "like products." Before turning to this question, it is helpful to consider the evolution of the term "like products" within the GATT.

Given the weighty consequences of the term "like products," one might imagine that its inclusion during the original drafting of the GATT would have been informed by a well-articulated agreement as to its meaning. This,

22 In this context, it has been suggested that the GATT - and particularly provisions like Article III-is to national governments what the Dormant Commerce Clause is to state governments. See James H. Snelson, Can GATT Article III Recover From Its Head-On Collision With United States-Taxes on Automobiles?, 5 MINN. J. Global TRADE 467, 467 (1996) (explaining the similarity between the GATT and the Dormant Commerce Clause doctrine of the U.S. Constitution).

${ }^{23}$ See Spain Tariff Treatment of Unroasted Coffee, June 11, 1981, GATT B.I.S.D. (28th Supp.) at 102, 107 (1982) (considering the quality of unroasted coffee).

${ }^{24}$ See United States Restrictions on Imports of Tuna, GATT B.I.S.D. (39th Supp.) at 155, $155-56$ (1992) (considering the quality of tuna catches).

${ }_{25}$ See Japan Customs Duties, Taxes and Labelling Practices on Imported Wines and Alcoholic Beverages, Nov. 10, 1987, GATT B.I.S.D. (34th Supp.) at 83, 85 (1988) (considering the quality of various imported wines and alcoholic beverages). 
however, was not the case. Originally, the drafters of Article III formulated no "precise definition" for the term "like products," deciding instead to leave that task to the proposed International Trade Organization ("ITO"). ${ }^{26}$ However, since the ITO never came into existence, ${ }^{27}$ the term was never officially invested with meaning. Thus, despite the powerful scope of the term, "the GATT has been functioning without a clear definition of like products since its inception., 28

\section{Factors Relevant to a "Like Products" Inquiry}

The failure of Article III to define "like products" has generated a fair number of disputes. Although far from uniform in their application, panels construing the "like products" clause have relied on a set of factors to determine whether a given import is sufficiently "like" a domestic product to secure national treatment by the importing country. A 1970 report entitled Border Tax Adjustments ("Border Tax") announced that the concept of like products "should be examined on a case-by-case basis ... [in light of such factors as] the product's end-uses in a given market[,] consumers' tastes and habits ... [and] the product['s] properties, nature and quality."29

It has been suggested that, until recently, the application of the Border Tax factors by GATT panels could be characterized as mechanical and textualist, "focused on the physical characteristics and end-uses of the products involved." ${ }^{, 30}$ Exemplary of this mechanical application is a 1987 panel decision finding likeness between imported vodka and the Japanese alcoholic beverage shochu because "they were both white/clean spirits, made of similar raw materials, and their end-uses were virtually identical (either as straight 'schnaps' [sic] type of drinks or in various mixtures).,

The mechanical approach is contrasted with a more intent-based "like products" analysis, under which imported and domestic goods are deemed like products only when the tax measure in question is applied so as "to af-

${ }^{26}$ William J. Snape, III \& Naomi B. Lefkovitz, Searching for GATT's Environmental Miranda: Are "Process Standards" Getting "Due Process?", 27 CORNELL INT'L L.J. 777, 792 (1994).

27 See John H. Jackson, National Treatment Obligations and Non-tariff Barriers, 10 MICH. J. INT'L L. 207, 207 (1989) (noting that the ITO did not come into existence).

${ }^{28}$ Snape \& Lefkovitz, supra note 26 , at 792.

29 Periodicals Panel Report, supra note 3, 73.73 [hereinafter Border Tax factors].

${ }^{30}$ Snelson, supra note 22, at 480.

31 Id. (quoting GATT Dispute Resolution Panel, Japan Customs Duties, Taxes and Labelling Practices on Imported Wines and Alcoholic Beverages, Nov. 10, 1987, GATT B.I.S.D. (34th Supp.) at 83, 117 (1988)). 
ford protection to domestic production."32 This intent-based inquiry is most apparent in United States Taxes on Automobiles ("Automobiles"), in which the panel considered whether the American Gas-Guzzler Tax was applied so as to afford protection to domestic producers. ${ }^{33}$ In finding that the seemingly pro-environment tax was not so applied, the Automobiles panel interpreted Article III to mean that a measure in violation of the Article would be one applied with the aim, as well as the effect, of affording protection to domestic production. ${ }^{34}$ Under this intent-based inquiry, any legitimate policy objective supporting the internal tax measure would have the salutary effect of curing the measure's potential inconsistency with Article III obligations. For the Gas-Guzzler Tax in Automobiles, such a curative policy objective was both clear and legitimate: the conservation of fossil fuels. ${ }^{35}$

After the decision in Automobiles, some worried that the panel's abandonment of a strict textual interpretation would hamper the GATT's ability to restrict the regulatory protectionism of Member nations. ${ }^{36}$ Indeed, had the Periodicals AB adhered to the aim-and-effect test in the Automobiles decision, Canada may well have prevailed by arguing that its cultural policies lacked the strict aim of protecting domestic production, but instead sought to preserve some medium for the expression of cultural identity.

By all accounts, however, the AB recently abandoned the intent-based inquiry in Japan Taxes on Alcoholic Beverages ("Alcoholic Beverages"). The AB explained:

[An Article III inquiry] is not an issue of intent. It is not necessary for a panel to sort through the many reasons legislators and regulators often have for what they do and weigh the relative significance of those reasons to establish legislative or regulatory intent. If the measure is applied to imported or domestic products so as to afford protection to domestic production, then it

32 Snelson, supra note 22, at 487, 495 (discussing the intent-based approach to Article III analysis).

33 GATT Dispute Panel Report on United States Taxes on Automobiles, 33 I.L.M. 1397, 1448 (Oct. 11, 1994) (analyzing the meaning of the phrase "so as to afford protection" in the context of the agreement).

${ }^{34}$ See id. (explaining that protection to the domestic industry violates the second sentence of Article III if it is the "desired outcome and not merely an incidental consequence of the pursuit of a legitimate policy goal").

${ }^{35}$ See id. at 1450 (summarizing the Panel's conclusion that the Gas Guzzler Tax did not target foreign vehicles).

${ }^{36}$ See Snelson, supra note 22, at 487-88 (noting that the Automobiles decision was evidence of the GATT's tolerance of facially neutral taxes which had no aim other than protectionism). 

does not matter that there may not have been any desire to engage in
protectionism...

Indeed, after the $\mathrm{AB}$ report in Alcoholic Beverages, the prospects for dismantling Canada's levee of cultural legislation ripened considerably.

\section{PlaCING PERIODICALS IN A HISTORICAL CONTEXT}

\section{A. Canada as a Market for U.S. Cultural Production}

Canada is the biggest export market for U.S. popular culture. ${ }^{38}$ Although a wealth of literature chronicles the U.S. cultural industries' rise and capture of Canadian markets, ${ }^{39}$ it is not the aim of this Comment to contribute significantly in this area. Nevertheless, it will be instructive to place into context the appearance of the split-run magazine Sports Illustrated Canada on the Canadian newsstands, if only to appreciate the magnitude and consequences of the dispute.

Many agree that certain characteristics of Canadian culture render the nation particularly sensitive to the cultural hegemony of the United States. Principal among these factors is language: since seventy percent of the Canadian population speaks English, the export of U.S. mass culture is not mediated for Canadians by an intervening language. ${ }^{40}$ Consequently, the content of U.S. products need not be translated for the Canadian market, and

37 See WTO Report of the Appellate Body, Japan Taxes on Alcoholic Beverages, WT/DS8/AB/R (Oct. 4, 1996) at 27-28 (emphasis added). Two facts about the Automobiles report help explain why its interpretations of the GATT law were so quickly abandoned in Alcoholic Beverages. First, the Automobiles panel report was never adopted, suggesting that, whatever weight is to be accorded prior panel interpretations of law (itself an open question under the WTO), in Automobiles this justification was absent. Snelson says that the panel report "fell into the twilight zone between GATT dispute resolution procedures and the new WTO regime." Snelson, supra note 22, at 487. U.S. Trade Representative Mickey Kantor nonetheless surmised that the panel report would "help steer the debate when GATT countries take up trade and environment issues under the new World Trade Organization." Id. at 487 n.117.

Of greater interest are speculations about the political dynamics at work in the panel's uncharacteristically pro-protectionist reading of Article III:2. Indeed, some commentators have suggested that the opinion-which finds room in the GATT for a U.S. domestic policy otherwise in violation - served a desire "to appease U.S. congressional opponents to U.S. membership in the WTO." Id. at 487 (citations omitted).

38 See Thompson, supra note 8, at 275.

39 See, e.g., Michael Braun \& Leigh Parker, Trade in Culture: Consumable Product or Cherished Articulation of a Nation's Soul?, 22 DENV. J. INT'L L. \& POL'Y 155, 160 (1993) (summing up Canada's arguments for protecting an endangered culture from American influence despite language similarity, geographical proximity, and common heritage).

${ }^{40}$ See Thompson, supra note 8 , at 271 (explaining the importance of language similarity in the influence of American culture). 
the U.S. producer faces no great expense in getting products to consumers. Moreover, whatever cultural influences one might ascribe to the U.S. product in Canada, they are unchallenged at the level of language. Thus, the story is told of the evolution of Miranda and Miranda-type rights in Canada:

Despite their different constitutional and political system, which had no explicit bill of rights, a great number of Canadians apparently believed that they had "the right to keep silent, the right to counsel," and so forth. Canada did add a bill of rights [but t]his came about at least in part because the average Canadian already assumed such rights. Television hardly played a negligible role here. $^{41}$

Contemporary demography is another factor facilitating U.S. cultural hegemony in North America. Eighty percent of the Canadian population is clustered within 100 kilometers of the U.S. border ${ }^{42}$ - a boundary that is increasingly porous, as the private sectors of both nations begin to reap the benefits of liberalized trade under the NAFTA.

Of course, Periodicals also signals the waning of geographical proximity as a priority for trade relationships, insofar as satellite technology renders the rest of the globe essentially as proximate as Canada for the purposes of the split-run magazine. And while other factors help explain the U.S. cultural dominance of North America, the Periodicals case is most instructive when viewed as an instance of a more general and evolving relationship between global trade and culture.

\section{B. The Canadian Magazine Industry and Domestic Policies}

The U.S. periodicals industry is exemplary of the success enjoyed by the export of U.S. cultural products to Canada. The dominance of U.S. magazines in Canada dates back to the second quarter of this century. In 1925, there were four U.S. magazines with Canadian circulations exceeding Maclean' $s$, ${ }^{43}$ then and now the leading Canadian-produced publication. ${ }^{44}$ At that time, the U.S.-produced Saturday Evening Post could truthfully promote itself as "Canada's best-selling magazine." this fact was not lost on the Canadian nationalist intelligentsia, who warned

41 Stephen R. Konigsberg, Note, Think Globally, Act Locally: North American Free Trade, Canadian Cultural Industry Exemption, and the Liberalization of the Broadcast Ownership Laws, 12 CARDOZO ARTS \& ENT. L.J. 281, 296 n.106 (1994) (quoting GEORGE H. QUESTER, THE INIERNATIONAL POLITICS OF TELEVISION 110 (1990)) (emphasis added).

${ }^{42}$ See id.

43 See id, at 272 .

44 Id. (noting the predominance of Maclean's).

${ }^{45}$ Id. 
that the steady advance of U.S. mass culture was "a menace to Canadian ideals and to the moral development of the youth of [Canada].

Post-World War II governmental initiatives to protect Canadian culture can be traced to the so-called Massey Report, which recommended an inquiry into those "institutions which express national feeling, promote common understanding and add to the variety and richness of Canadian life, rural as well as urban." The Massey Report became the "cornerstone,48 of Canada's array of government cultural subsidies, which sought to counterbalance the enormous sums spent on the arts by wealthy U.S. business interests. $^{49}$

\section{The Electronic Split-Run}

In 1965, with anti-American sentiment particularly acute in Canada, Prime Minister Lester Pearson's Liberal government enacted Tariff Code $9958,{ }^{50}$ prohibiting the importation of split-run magazines into Canada. ${ }^{51} \mathrm{~A}$ "split-run" edition of a magazine is produced

by separating ("splitting") the editorial content (articles, photographs, artwork, etc.) and the advertising content of the magazine. The publisher then produces two or more separate regional editions of the issue of the magazine. Each edition shares some or all of the editorial content, but the advertising content in each edition may differ, because each edition is distributed in a different geographic market and the advertising is directed at that specific market. ${ }^{52}$

In the three decades that followed, Tariff Code 9958 frustrated the efforts of U.S. publications seeking entry into the Canadian market.

By March of 1996, however, when the United States filed a complaint with the WTO, Tariff Code 9958 had ceased to be an effective gatekeeper in protecting the Canadian market from split-run imports. Time Warner's audacious application of satellite technology to the production of split-run magazine editions enabled the electronic transmission into Canada of U.S.-

${ }^{46} I d$.

47 Konigsberg, supra note 41, at 290 n.64 (citing Royal Commission on National Development in the Arts, Letters and Sciences (1949-51) (Can.)).

48 Id. at 290 (describing the impact of the Massey Report).

49 See id. at 290-91 \& n.66 (noting the "lavish private support of the arts by owners of huge fortunes, including the so-called robber barons," in the United States).

50 Customs Tariff, R.S.C., ch. 41 (3d Supp.), § 114, sched. VII, item 9958 (1996) (Can.).

51 See Schofield, supra note 6, at 45 (explaining the history of what became Tariff Code 9958).

52 Periodicals Panel Report, supra note $3, \llbracket 3.23$ 
manufactured editorial content. ${ }^{53}$ The digital editorial content, received in Canada as a satellite transmission, was then assembled in magazine form. Printing technology facilitated the cheap, mass reproduction of the imported editorial content, to which were attached advertisements directed at the consuming market. The most significant legal point about Time Warner's splitrun magazine was that, because it was technically "printed" in Canada, it was not subject to the import prohibition of Tariff Code 9958.

A split-run magazine is virtually identical to its original in all respects except one-the advertisements. Magazines traditionally generate revenue in two ways: from sales of the physical magazine itself and from sales of advertising space in the magazine. Both sources of revenue are vital to the magazine's economic viability. ${ }^{54}$ Because the split-run edition of Sports Illustrated Canada will capture some part of the fixed advertising dollars paid by Canadian advertisers to reach a Canadian audience, correspondingly less of those dollars will support the domestic magazine industry in Canada. Moreover, evidence indicates that the ultimate viability of Canada's magazine industry depends on access to these domestic advertising revenues, in part because Canadian-produced magazines historically have had very little international appeal. $^{55}$

The foreign market is an attractive opportunity for the U.S. producer, who will realize a profit whenever "the incremental revenue from advertising in the regional edition exceeds the costs of producing the split-run. ${ }^{56}$ Where a magazine has an established U.S. market before contemplating a Canadian version (which is certainly the case with Sports Illustrated), the fixed costs of production will largely have been recovered in the home market. Consequently, on the margin, it is very inexpensive to produce the split-run edition. The savings in production costs for the split-run producer

${ }^{53}$ See generally Tina W. Chao, Comment, GATT's Cultural Exemption of Audiovisual Trade: The United States May Have Lost the Battle But Not the War, 17 U. PA. J. INT'L ECON. L. 1127, 1149 (1996) (describing the impact of technological advances on international broadcasting regulations).

54 One insider predicts that the Periodicals ruling will cost Canadian magazine producers $37 \%$ of their advertising revenues. See Marci McDonald, Menacing Magazines, MACLEAN's, Mar. 24, 1997, at 54, 54 (reporting on the Canadian response to the Periodicals decision). According to the president of Canada's largest publisher, a mere $15 \%$ loss of advertising revenues could mean "the difference between having a viable magazine and an eking-by magazine." Id.

${ }_{55}$ See infra notes 56-60 and accompanying text (explaining the unique trade problems presented by split-run magazines). See also Robert Lewis, When Culture is Attacked, MACLEAN'S, Mar. 24, 1997, at 4, 4 ("The strength of the Canadian periodical publishing sector is its commitment to stories that travel well in Canada, but not necessarily in a global market.").

Periodicals Panel Report, supra note 3, 13.30. 
yield a competitive advantage against domestically produced magazines whose production costs must be fully recovered in a purely domestic (hence, smaller) market. This advantage may be reflected in any number of factors, including a wider subscription base and a greater share of the available advertising revenue. In addition, lower subscription prices for the split-run can force out similar domestic magazines, which, as explained, depend mightily on domestic advertising revenues.

The editor-in-chief of Maclean's, Robert Lewis, explains the concern of Canadian publishers. Because advertising revenues in Canada constitute a "finite pool," Lewis concludes that "if foreign publications are going to take a larger chunk of it, [Maclean's has] less money to send reporters out to do Canadian stories." ${ }^{, 57}$ Indeed, because Canadian magazines operate with a comparatively low profit margin of approximately five percent, ${ }^{58}$ the Canadian Magazine Publishers Association (the "CMPA") greatly fears the loss of advertising revenue to imported split-run magazines. The CMPA estimated that a three percent diversion of Canadian advertising dollars to U.S. publications could wipe out the domestic industry's profits altogether. ${ }^{59}$ CMPA President Catherine Keachie puts the issue more bluntly: "You can't compete for advertising with publications that have no [editorial] costs." 60

\section{What is at Stake in Periodicals?}

In real terms, Periodicals addresses the viability of the entire Canadian magazine industry, composed of 1400 consumer and trade magazines and accounting in 1996 for $\$ 867$ million in advertising revenues. ${ }^{61}$ Such enormous stakes tempt one to adopt a purely economic reading of the dispute, categorizing the magazine as one of many private goods-like cotton yarn,

57 McDonald, supra note 16 , at 59.

58 See Lewis, supra note 55, at 4 ("[P]rofit margins-averaging about 5 per cent for magazines-are modest compared with many industries, and depend mightily on advertising revenue.").

59 See Van Harpen, supra note 15, at 173-74 (describing various economic threats to the Canadian magazine industry). According to the CMPA, "[ $[$ ] $]$ he Canadian magazine industry remains in a developmental stage; publishers have not reached the maturity and powerful financial position of their American counterparts." Id. at 173. The CMPA further suggested that advertising sales by Sports Illustrated Canada might run afoul of Canadian dumping laws, "not because its advertisement prices per thousand subscribers were low, but because it averages five readers per copy while two major Canadian publications average 1.1 and 1.9 readers per copy." Id. at 174 n.43.

60 Schofield, supra note 6, at 45.

61 See id. at 44-45 (documenting the possible threat to Canadian journalism resulting from the Periodicals decision). 
yogurt, and non-rubber footwear-for which trade relationships are readily assimilated to the terms of the GATT.

To rely on this private good categorization, however, is to neglect the magazine's transcendence of the parochial and economic interests of its own industry. Unlike purely private goods, magazines have important public good characteristics-chiefly, the intellectual content that magazines are in the business of disseminating. ${ }^{62}$ The historical importance of magazines as fora for the exchange of ideas and information, and therefore for the establishment and exploration of local, national, and other forms of consciousness, hardly needs documentation.

The Canadian perspective in print form is also vital to the exercise of democracy in Canada. Magazines inform Canadians about the social, political, and economic happenings of their nation (or metropolis, township, neighborhood, interest group, etc.); magazines enable their readers to act politically and make informed decisions at the polls.

Moreover, magazines are vehicles for cultural expression. Canadian Pierre Berton put the case as follows:

As for culture-we [Canadians and Americans] don't even speak the same language. You think of culture in terms of opera, ballet, and classical music. To us it covers everything from Stompin' Tom Connors to Hockey Night in Canada. ... Maclean's magazine is culture .... [These are all] genuine Canadian artifacts, distinct and unique, something we have that nobody else hasthe ingredients of our national mucilage.

Applying Berton's perspective, the Periodicals case takes on the proportions of an epic. The disappearance of Canada's "mucilage" suggests a fragmented national culture incapable of reincorporation. Culture, though itself a concept of inestimable complexity, ${ }^{64}$ customarily has given rise to specific, non-economic interests protected by international law. ${ }^{65}$ From that

${ }^{62}$ For a discussion of "public goods" and "private goods," see infra notes 128-33 and accompanying text.

63 PIERRE Berton, Why We Act like Canadians: A Personal Exploration of OUR NATIONAL CHARACTER 9 (1987).

${ }^{64}$ See, e.g., RAYMOND WILLIAMS, KEYWORDS: A VOCABULARY OF CULTURE AND SOCIETY 87 (1985). Williams writes:

Culture is one of the two or three most complicated words in the English language.

This is so partly because of its intricate historical development, in several European languages, but mainly because it has now come to be used for important concepts in several distinct intellectual disciplines and in several distinct and incompatible systems of thought.

Id.

${ }^{65}$ See, e.g., Braun \& Parker, supra note 39, at 173. Braun \& Parker write:

The preservation of cultural values and national identity as a component of sovereignty is a well established goal of international agreements. For example, Article 
perspective, Periodicals allegorizes the struggle between non-economic interests, on the one hand, and the sometimes antagonistic globalization of free trade, on the other. ${ }^{66}$ Part III closely examines the Periodicals litigation-the narrative through which this allegory is played out.

\section{THE PERIODICALS LITIGATION}

\section{A. The Periodicals Dispute}

The procedural history of Periodicals began when the United States filed a complaint with the WTO, arguing, inter alia, that recently enacted Canadian legislation violated obligations under the GATT. The offending legislation, Bill C-103, ${ }^{67}$ attempted to plug the loophole in Tariff Code 9958, through which Time Warner transmitted the editorial content of splitrun magazines via satellite. ${ }^{68}$ Bill C-103 imposed an eighty percent tax on the value of all advertisements contained in a split-run edition. ${ }^{69}$ Such an aggressive tax, which caused Time Warner to hold back its Canadian version of Sports Illustrated, "risk[ed] the wrath of the United States." suant to WTO procedure, the United States requested consultations with Canada. $^{71}$

19 of the Universal Declaration of Human Rights promulgated by the General Assembly of the United Nations in 1948 recognizes free expression as a fundamental human right. Similarly, Article 1(1) of the International Covenant on Civil and Political Rights affirms the right of all peoples to "freely determine their political status and freely pursue their economic, social and cultural development."

Id. (citations omitted). For a different perspective, see the Final Report of the UNESCO World Conference on Cultural Policies: "Creative human activity and the full development of the individual and society depend upon the widest possible dissemination of ideas and knowledge by way of cultural exchange and contacts." Konigsberg, supra note 41, at 301 (citing UNESCO World Conference on Cultural Policies: Final Report, Mex. City, July 26-Aug. 6, 1982).

${ }^{66}$ Many of the effects of free trade have been positive for the development of national cultures. For instance, free trade has made video cameras-a technology not produced by all nations-widely accessible as a medium for expression. Furthermore, competitive international forces motivate domestic indusiries to operate with more efficiency in order to support national culture. On this point, see de Fazekas, supra note 9, at 158-59, deconstructing the myth that free trade has only negative consequences for Canadian cultural industries.

${ }_{68}$ Act to Amend the Excise Tax Act and the Income Tax Act, ch. 46, 1995 S.C. (Can.).

68 See supra notes 52-53 and accompanying text (describing the process by which splitrun magazines are published).

69 See Periodicals Panel Report, supra note 3, \ 2.6 (describing Bill C-103).

70 John Schofield, Back to Square 1, MACLEAN's, July 14, 1997, at 36, 36 (describing the possible effects of the Periodicals appellate decision).

${ }^{71}$ Consultations between Member nations are provided for by article 4 of the Understanding on Rules and Procedures Governing the Settlement of Disputes and article XXIII of 
After consultations between the United States and Canada failed to reach a satisfactory conclusion, the Dispute Settlement Body established a panel to review the matter. ${ }^{72}$ In its submission, the United States requested that the Panel make three findings. First, the United States argued that the prohibition on the importation of certain split-run magazines mandated by Tariff Code 9958 violated Canada's obligations under GATT Article III, which generally prevents quantitative restrictions on most imported products. $^{73}$ On this issue, the Panel agreed with the United States, and the AB subsequently affirmed the Panel's finding. ${ }^{74}$

Second, the United States claimed that Canada's lower postal rates for domestically-produced periodicals were inconsistent with the Article III assurances of nondiscriminatory treatment, and could not be justified as a "payment of subsidies exclusively to domestic producers."75 Canada prevailed on this issue at the panel level, ${ }^{76}$ but the $A B$ ultimately overturned the decision, concluding that the Canadian postal subsidies were not justified under Article III. ${ }^{77}$

The third U.S. claim, arising under GATT Article III, paragraph two ("Article III:2") is the focal point of this Comment.

\section{B. Article III:2}

The U.S. claims that Canada's eighty percent excise tax on imported split-run magazines violates Article III:2, the first sentence of which provides:

the GATT. See Periodicals Panel Report, supra note 3, I 1.1 (documenting that the United States requested that Canada hold consultations pursuant to both provisions).

${ }^{72}$ See id. $\llbracket 1.1$ (finding that a panel was necessary for further examination of the matter).

73 See Periodicals Panel Report, supra note 3, ๆ 3.3 ("The United States argued that the Canadian import prohibition on the products listed in Tariff Code 9958 is a violation of Article XI:1 of GATT 1994, which prohibits quantitative restrictions on imports.").

${ }_{75}^{74}$ See Periodicals AB Report, supra note 3, at *24 (upholding the Panel's findings).

75 Periodicals Panel Report, supra note 3, โโ 3.1, 3.182 (arguing that Canada Post's discriminatory postal rates violated Article III).

${ }^{76}$ See id. supra note $3,16.1$ (finding that "the maintenance of the 'funded" rate scheme is justified").

77 See Periodicals AB Report, supra note 3, at *24 (finding the rate scheme unjustified). The ultimate resolution of this issue turned on the form of the Canadian postal subsidy. The United States successfully argued to the $\mathrm{AB}$ that the subsidy was more like a transfer between government agencies than a direct payment from the government to the domestic producers. See id. In overturning the Panel, the AB found a separation of tax and subsidy rules preferable because it leads to "greater transparency." Id. The costly result for Canada is that the continuing subsidization of the Canadian periodicals industry must take the form of direct payments from the government. 
The products of the territory of any contracting party imported into the territory of any other contracting party shall not be subject, directly or indirectly, to internal taxes or other internal charges of any kind in excess of those applied, directly or indirectly, to like domestic products. 78

Under this first sentence of Article III:2, hereinafter referred to as the "like products" clause, a Member nation may argue that its product, when imported by another Member nation, faces discriminatory taxation-that is, taxation not faced by "like domestic products." The United States made this claim with respect to the split-run magazine. In Periodicals, the issue under the "like products" clause became whether domestic non-split-run magazines and imported split-run magazines were "like products."

The second sentence of Article III:2, hereinafter referred to as the "directly competitive" clause, reads:

Moreover, no contracting party shall otherwise apply internal taxes or other internal charges to imported or domestic products in a manner contrary to the principles set forth in paragraph $1 .^{79}$

A later addition to paragraph two introduces the "directly competitive" language, and clarifies the legal relationship between the two clauses of Article III:2:

A tax conforming to the requirements of the first sentence of paragraph 2 ["like products" clause] would be considered to be inconsistent with the provisions of the second sentence ["directly competitive" clause] only in cases where competition was involved between, on the one hand, the taxed product and, on the other hand, a directly competitive or substitutable product which was not similarly taxed. ${ }^{80}$

Thus, in Periodicals, the inquiry under the "directly competitive" clause became whether domestic non-split-run magazines and imported split-run magazines were "directly competitive or substitutable."

A complaining Member can argue an Article III:2 violation under either the "like products" or the "directly competitive" clauses. Thus, a national treatment violation can be established if the imported product is either "like" the domestic product, or "directly competitive or substitutable" with that product. The table below indicates the Panel's resolution of the issues under both clauses of Article III:2, as well as the AB's treatment of those same issues on appeal.

${ }^{80}$ GATT, supra note 4, Annex I, ad art. III, ๆ 2 (emphasis added). 


\begin{tabular}{|c|c|c|}
\hline & WTO Panel Report & WTO AB Report \\
\hline $\begin{array}{l}\text { The Narrow "Like } \\
\text { Products" Clause: } \\
\text { Are domestic maga- } \\
\text { zines and imported } \\
\text { split-run magazines } \\
\text { "like products"? }\end{array}$ & $\begin{array}{l}Y E S \text {, they "can be like } \\
\text { products." } \\
\text { fore, the excise tax is } \\
\text { inconsistent with Arti- } \\
\text { cle III: } 2 \text {. }\end{array}$ & $\begin{array}{l}\text { Vacated Panel finding, } \\
\text { but made no inde- } \\
\text { pendent finding. }\end{array}$ \\
\hline $\begin{array}{l}\text { The Broad Directly } \\
\text { Competitive Clause: } \\
\text { Are domestic maga- } \\
\text { zines and imported } \\
\text { split-run magazines } \\
\text { "directly competitive } \\
\text { or substitutable"? }\end{array}$ & $\begin{array}{l}\text { Not addressed, be- } \\
\text { cause the Panel found } \\
\text { "like products" under } \\
\text { the like products } \\
\text { clause. }\end{array}$ & $\begin{array}{l}Y E S \text {, they are "directly } \\
\text { competitive or substi- } \\
\text { tutable." } 83 \text { Therefore, } \\
\text { the excise tax is incon- } \\
\text { sistent with Article } \\
\text { III:2. }\end{array}$ \\
\hline
\end{tabular}

For the moment, it should be noted that the "like products" issue was never resolved. As the table reveals, the AB rejected the Panel's analysis of that issue, and instead reached its holding of violation by means of the "directly competitive" clause. ${ }^{84}$

\section{The "Like Products" Clause Analysis in Periodicals}

The Panel found that domestic magazines and imported split-run magazines "can be like products within the meaning of Article III:2." the import restriction of Tariff Code 9958, there were no imported split-runs

${ }^{81}$ Periodicals Panel Report, supra note 3, I 5.26. The Panel's analysis failed, however, to apply the factors necessary to a "like products" determination, and instead relied on a hypothetical later discredited by the AB. See infra note 86 and accompanying text (describing the Panel's hypothetical).

${ }^{82}$ See Periodicals AB Report, supra note 3, at *15-16. The Panel's affirmative finding of "like products" was reversed by the $\mathrm{AB}$ because it was based on a flawed hypothetical. See id. at * 15 . The AB found that the hypothetical postulated "two editions of the same magazine, both imported products, which could not have been in the Canadian market at the same time." Id. Thus, the AB ruled that the Panel "could not logically arrive" at its reported conclusion, nor, given the "inadequate factual analysis" of the Panel, could the AB itself "proceed to a determination of like products." Id. at *16.

${ }^{83}$ Id. at *20 ("[I]mported split-run periodicals and domestic non-split-run periodicals are directly competitive or substitutable products in so far as they are part of the same segment of the Canadian market for periodicals." (emphasis added)).

\footnotetext{
84 See id. at *16-20 (analyzing Article III:2).

${ }^{85}$ Periodicals Panel Report, supra note 3, ๆ 5.26.
} 
in Canada. The Panel, therefore, based its analysis on a hypothetical example. ${ }^{86}$ However, Canada, the United States, and finally the $A B$ concluded that the hypothetical was flawed since it compared "two editions of the same magazine, both imported products, which could not have been in the Canadian market at the same time., ${ }^{, 87}$

More revealing than the Panel's flawed hypothetical was its justification for relying on one in the first place. Citing a prior panel report, the Panel asserted that Article III was drafted "to protect expectations of the Members as to the competitive relationship between their products and those of other Members. ${ }^{\text {\$88 }}$ In its reliance on a hypothetical example, however, the Panel elided any application of the explicit factors announced in the Border Tax report. Accordingly, the AB found the Panel's conclusion impoverished by "inadequate factual analysis," and therefore reversed on the "like products" issue. 89

The Border Tax factors-"'the product's end-uses in a given market, consumer's tastes and habits, and the product's properties, nature and qual-

${ }^{86}$ In the relatively confusing hypothetical, the Panel compared the U.S. and Canadian editions of Harrowsmith Country Life, a Canadian-owned magazine.

[I]f all the volumes of Harrowsmith Country Life had been printed in the United States (including its Canadian edition) and the Canadian edition had been exported to Canada because they were somehow exempted from the coverage of Tariff Code 9958, and if the publisher decided to publish the final issue of the US edition after the introduction of the excise tax, the publisher would have been subject to the tax for the imported Canadian edition. If this publisher thereafter discontinued the publication of the US edition, it would no longer be subject to the excise tax. Now, let us compare the two issues of this hypothetical Harrowsmith Country Life (Canadian edition) before and after the discontinuation of the US edition. These two editions would have common end uses, very similar physical properties, nature and qualities ... designed for the same readership with the same tastes and habits. In all respects, these two volumes are "like," and yet one is subject to the Excise Tax, while the other is not.

Id. T 5.25 .

${ }_{87}$ Periodicals AB Report, supra note 3, at *15.

${ }^{88}$ Periodicals Panel Report, supra note 3, I 5.23 (emphasis added). The negotiating history of Article III suggests that it had two main purposes:

This Article in the Charter had two purposes, as I understand it. The first purpose was to protect the items in the Schedule or any other Schedule concluded as a result of any subsequent negotiations and agreements-that is, to ensure that a country offering a tariff concession could not nullify that tariff concession by imposing an internal tax on the commodity, which had an equivalent effect.... But [Article III] had an additional purpose ... to prevent the use of internal taxes as a system of protection. It was part of a series of Articles designed to concentrate national protective measures into the forms permitted under the Charter, i.e. subsidies and tariffs .... [Thus, Article III ensures] that the tariff concessions [countries] grant one another cannot be nullified by the imposition of corresponding internal taxes ....

Japan Taxes on Alcoholic Beverages, supra note 37, at 17 n.39.

89 Periodicals AB Report, supra note 3, at *16 (reversing the Panel's decision). 
ity" 90 -provide the basis for Canada's best arguments. The end use of a magazine with a Canadian perspective is different from that of a magazine with a U.S. perspective. For instance, an article published in Maclean's might support the hypothetical political candidacy of a woman running for mayor in Ottawa, whereas no split-run would provide her with similar, relevant content. This difference in perspective certainly registers consumer's tastes and habits through the circulation of split-runs relative to domestic magazines. Finally, consistent with the preceding two factors, the properties, nature and quality of the magazines are easily distinguished by their differing content and editorial perspective.

Without examination of the Border Tax factors in light of the particular circumstances of Periodicals, an abstract "expectation" of a particular "competitive relationship" too readily eliminates from consideration the non-economic interests in maintaining a Canadian magazine industry. Moreover, as a matter of GATT doctrine, competitive relationships are more properly the subject of the "directly competitive" clause of Article III:2. Importing the yardstick of competition into the "like products" analysis has the effect of obliterating any distinction between the two, independent clauses in Article III:2-a distinction known to exist because it was openly articulated by a GATT panel. ${ }^{91}$

In any event, the Border Tax factors were never applied, nor was any shred of the Panel's "like products" analysis accepted by the AB. However, the three-member $A B$ was not content with reversing the Panel's "like products" analysis, and decided that its scope of review also extended to consideration of the "directly competitive" clause of Article III:2. The AB cited "sufficient basis in the panel record" to render an analysis, and thought that by conducting the analysis itself it could accommodate the WTO's interest in "prompt settlement of disputes." The $\mathrm{AB}$ extended its scope, however, in the face of Canada's protestations that the United States could not appeal the issue under the "directly competitive" clause because, among

90 Periodicals Panel Report, supra note 3, 75.22.

91 See United States Measures Affecting Alcoholic and Malt Beverages, June 19, 1992 , GATT B.I.S.D. (39th Supp.) at 277 (1993) (explaining how two unlike wines "would nevertheless have to be regarded as "directly competitive"'); Snelson, supra note 22, at 480-81 n.80 ("Ad Article III would be meaningless, however, if its language were not more expansive than that of Article III:2, first sentence.").

92 Periodicals AB Report, supra note 3, at *16 ("As the legal obligations in the first and second sentences are two closely-linked steps in determining the consistency of an internal tax measure with the national treatment obligations of Article III:2, the Appellate Body would be remiss in not completing the analysis of Article III:2."). 
other things, the Panel did not even address it. ${ }^{93}$ Indeed, GATT doctrine expressly limits the AB's scope of review of panel decisions to "issues of law covered in the panel report and legal interpretations developed by the panel," 94 neither of which, in this case, involved the "directly competitive" clause. Nonetheless, the $\mathrm{AB}$ proceeded to complete the analysis and found that the magazines in question were "directly competitive." 95

\section{The "Directly Competitive" Clause Analysis in Periodicals}

The substantive legal importance of the AB's procedural maneuver becomes evident after clarification of the relationship between the "like products" and "directly competitive" clauses. Of the two clauses, the "directly competitive" clause most unambiguously embodies the ideal of unfettered global free trade. By its terms, the "directly competitive" clause apprehends internationally traded products by their competitive relationship, rather than through a comparative analysis of the products themselves, as under the "like products" clause. (In this respect, Article III can be likened to the Dormant Commerce Clause, restricting Member nations from overly regulating trade between themselves much as states are restricted from regulating interstate commerce.) $)^{96}$

The decisive criterion in analyzing products under the "directly competitive" clause is whether they have common end-uses. ${ }^{97}$ The concept of cross-price elasticity attempts to measure the commonality of the end-uses of two products by tracking how demand for one good reacts to changes in the price of another good. ${ }^{98}$ By generating this empirical data, cross-price elasticity of demand purports to answer the question whether one product is

93 See id. ("Canada asserts that the Appellate Body does not have jurisdiction to examine a claim under Article III:2, second sentence, as no party has appealed the findings of the Panel on this provision.").

94 Understanding on Rules and Procedures Governing the Settlement of Disputes, Apr. 15, 1994, Marrakesh Agreement Establishing the World Trade Organization, Annex 2, in GATT, supra note 4, art. 17, \6.

95 See Periodicals AB Report, supra note 3, at *20 (noting that the imported and domestic products were directly competitive since they were part of the "same segment of the Canadian market for periodicals").

96 See Snelson, supra note 22, at 467 \& $n .1$ (explaining the comparison to the Dormant Commerce Clause doctrine).

97 See Japan Taxes on Alcoholic Beverages, supra note 37, at 25 (affirming the Panel's explanation that "the decisive criterion in order to determine whether two products are directly competitive or substitutable is whether they have common end-uses, inter alia, as shown by elasticity of substitution").

98 See, e.g., ROBERT S. PINDYCK \& DANIEL L. RUBINFELD, MICROECONOMICS 31-32 (2d ed. 1995) (explaining cross-price elasticity of demand). 
competitive with another. If so, then the "directly competitive" clause protects the imported product from discriminatory taxation.

Because Article III:2 violations can be established under either clause, the expansive regulatory embrace of the "directly competitive" clause threatens to eclipse the narrow, case-by-case analysis required by the "like products" clause. In fact, Periodicals amplifies this tension between the two clauses, suggesting that even where a litigant can successfully distinguish a domestic product from its imported competitor under the "like products" clause (as Canada might have), the "directly competitive" clause will likely render those distinctions irrelevant.

In this respect, the case highlights the shortcomings of cross-price elasticity of demand as a proxy for similarity of end-uses, since one can easily imagine periodicals that are cross-price elastic in demand but whose enduses are nonetheless distinguishable. ${ }^{99}$ Perhaps this is because magazines, consistent with their subject matter and audience, assemble a wide variety of information, which in turn supports a great number of end-uses. The similarity of these multitudinous end-uses, however, is not something the $A B$ was willing to probe; thus, the $\mathrm{AB}$ rejected the Canadian argument that, while domestic and imported split-run magazines "may be substitutable advertising vehicles, they are not competitive or substitutable information vehicles."100

In an effort to defeat the assertion that Canada applied its excise tax "so as to afford protection"- a necessary element under the "directly competitive" clause ${ }^{101}$ - Canada submitted that the tax sought to secure the survival of the Canadian periodical industry, a "vital element of Canadian cultural expression." 102 Consistent with recent GATT interpre-

${ }^{99}$ For instance, consider magazines A and B. Magazine A contains national news and local news, whereas magazine $B$ contains only national news. With respect to the market for national news, magazines $A$ and $B$ can be cross-price elastic in terms of demand. Yet the fact that magazine $A$ contains local news indicates that its end-use could be distinguishable from the end-use of magazine $B$, which does not contain local news.

${ }^{100}$ Periodicals AB Report, supra note 3, at *18 (emphasis added).

101 The three elements are whether:

(1) the imported products and the domestic products are "directly competitive or substitutable products" which are in competition with each other;

(2) the directly competitive or substitutable imported and domestic products are "not similarly taxed"; and

(3) the dissimilar taxation of the directly competitive or substitutable imported domestic products is "applied ... so as to afford protection to domestic production."

Japan Taxes on Alcoholic Beverages, supra note 37, at 24.

${ }^{102}$ Periodicals AB Report, supra note 3, at *21 (quoting Japan Taxes on Alcoholic Beverages, supra note 37, at 29) ("[W]e are committed to ensuring that Canadians have access to Canadian ideas and information through genuinely Canadian magazines."). 
tations, ${ }^{103}$ however, the $\mathrm{AB}$ did not even consider Canada's legislative intent in enacting the excise tax.

Instead, the $\mathrm{AB}$ proceeded to "examine objectively the underlying criteria" 104 of the excise tax, and based on its decisively prohibitive magnitude, the $\mathrm{AB}$ readily concluded that the tax afforded protection to domestic products. Thus, Periodicals reiterates the WTO's departure-at least in the context of an Article III:2 analysis-from the aim-and-effect test. That test, which interpreted the phrase "so as to afford protection" to require proof of intent, might have permitted legislation whose aim was cultural but which had the corollary effect of protecting an industry. Given the tenor of the $P e$ riodicals reports, and the circumstances surrounding the GATT panel's brief experiment with the aim-and-effect test, it seems unlikely that the WTO will return to such an intent-sensitive analysis of domestic policy.

On September 2, 1997, when Canada formally signaled its intention to meet its GATT obligations, it reaffirmed its "intention to continue to pursue its cultural policy objectives." 105 After Periodicals, granting direct subsidies to publishers is among the few GATT-acceptable options left for Can$\mathrm{ada}^{106}$ - an arrangement of dependency that threatens the freedom and objectivity of the Canadian press.

The Periodicals decision has opened the door for similar challenges to Canadian industries and the legislation supporting them. Other potential areas where Canadian culture might have to yield: the distribution of feature films and book publishing; ${ }^{107}$ book distribution, where the U.S. bookstore Borders Inc. has pushed for a foothold in Canada; ${ }^{108}$ and broadcasting,

${ }^{103}$ See supra note 37 and accompanying text (noting that Article III inquiries are not intent-based and concluding that the prospects for deconstructing Canada's cultural legislation are therefore increased).

${ }^{104}$ Periodicals AB Report, supra note 3, at *21-22 (stating that there is "ample evidence that the very design and structure of [Part V.1 of the Excise Tax Act] is such as to afford protection to domestic periodicals").

105 Communication from Canada to the World Trade Organization, Canada Certain Measures Concerning Periodicals, Sept. 2, 1997, available in 1997 WL 537568.

106 See Aaron Scow, Note, The Sports Illustrated Canada Controversy: Canada "Strikes Out" In Its Bid to Protect Its Periodical Industry from U.S. Split Run Periodicals, 7 MnN. J. GLOBAL TRADE 245, 280 (1998) (arguing that a subsidy is Canada's best remaining option).

${ }^{107}$ See, e.g., McDonald, supra note 16, at 58 (suggesting that the ruling is "a precedent for U.S. challenges to [Canada's] other beleaguered cultural industries, from book publishing to broadcasting"); Canadian Officials, supra note 11 (suggesting that the ruling "could lead to pressure in other areas such as the distribution of feature films and television signals").

${ }_{108}$ See Mirko Bibic \& Jonathan Daniels, Canadian Government Affirms Cultural Policy, U.S. MEX. FREE TRADE REP., Nov. 15, 1996, available in 1996 WL 13938851 (discussing Country Music Television's access to Canadian subscribers). 
where Country Music Television was similarly thwarted in its bid to attract Canadian subscribers. ${ }^{109}$

\section{CUlture, Free TRADE, AND THE WTO}

\section{A. Elements of Culture in Periodicals}

The Periodicals case is of great interest, in part because the magazine sits uncomfortably within the provisions of GATT Article III-a provision broadly drafted fifty years ago to embrace the vast heterogeneity of products globally traded, from gasoline to rubber bands. Indeed, because of the magazine's hybrid quality -its mixture of public- and private-good characteristics, ${ }^{110}$ its debatable classification as a good and/or a service, and its role in the cultural development of a nation-the Article III text is subjected to interpretive pressures for which there is little precedent in GATT/WTO dispute settlement proceedings.

Canada sought to win the "like products" issue by drawing distinctions between split-run and domestic magazines on the basis of their cultural content. Following GATT precedent, Canada narrowly construed the "like products" inquiry, relying on the Border Tax factors. Applying these factors, Canada asserted that the "end-use" of the two magazines rendered them distinguishable, and made reference to the importance of intellectual content. According to Canada, "[c]ontent plays a role in the case of cultural products that is analogous to physical properties in the case of ordinary items of trade ... [it] is what the reader is looking for-the message and not the medium." $" 111$

But the Panel refused to acknowledge the force of this argument. One might have thought that, once the Panel had accepted the U.S. position that magazines were goods rather than services, ${ }^{112}$ it would have been compelled by conventional "like products" analysis to acknowledge distinctions among those goods on the basis of their content, as Canada correctly asserted. Indeed, on its review of the Panel decision, the $\mathrm{AB}$ readily conceded the logic

109 See id. at 2 (discussing attempts by U.S. bookseller Borders Inc. to open stores in Canada).

110 See infra notes 128-34 and accompanying text (noting that magazines are simultaneously nonrival (hence, public) and excludable (hence, private), endowing the term with a hybrid construction).

111 Periodicals Panel Report, supra note 3, ๆ 3.68.

112 See id. I 5.19 ("Thus, we conclude that Article III of GATT 1994 is applicable to Part V.1 of the Excise Tax Act."). 
of such a distinction. ${ }^{113}$ For procedural reasons discussed supra, however, the $\mathrm{AB}$ never completed a binding "like products" analysis, so that the $\mathrm{AB}$ never properly considered Canadian arguments over content distinctions. ${ }^{114}$ The Canadian submission underscored the bluntness of the WTO as an instrument for dispute resolution: "The implication is that one should look at the form, not the substance; that the assessment should be in the abstract and that the concrete effect should be ignored."

What is the "substance"? What is the "concrete effect" whose assessment is being neglected by the WTO dispute settlement mechanism? This Comment suggests that one should read Periodicals as an allegory of the increasingly contentious relationship between culture and free trade. As cultural historian Raymond Williams explained, the complexity of the concept of "culture" derives from the term's usage "in several distinct intellectual disciplines and in several distinct and incompatible systems of thought."16 The same terminological complexity attends the discipline of international trade; Periodicals underscores the need for isolating and examining the various meanings given to culture within that system of thought. Only then can culture be understood as suffering from a crisis of representation in that context.

Such an inquiry might begin by recognizing that the Canadian magazine industry is a cultural industry within the only international legal definition of that term, used in the NAFTA. ${ }^{17}$ In fact, Canada selected these industries for special treatment in the NAFTA since, historically, attempts at their

113 The $A B$ softened their conclusion that the magazines were "directly competitive or substitutable products," explaining that such a finding

does not mean that all periodicals belong to the same relevant market, whatever their editorial content. A periodical containing mainly current news is not directly competitive or substitutable with a periodical dedicated to gardening, chess, sports, music or cuisine. But news magazines, like TIME, TIME Canada and Maclean's, are directly competitive or substitutable in spite of the Canadian content of Maclean's.

Periodicals AB Report, supra note 3, at *20.

114 See supra notes 88-89 and accompanying text (noting that the $\mathrm{AB}$ found the Panel's conclusion on the "like products" issue to be factually inadequate).

115 Periodicals Panel Report, supra note 3, \3.88.

116 WILliAMS, supra note 64, at 87.

117 Cultural industries "means persons engaged in any of the following activities: (a) the publication, distribution, or sale of books, magazines, periodicals or newspapers in print or machine readable form ...." North American Free Trade Agreement, Dec. 17, 1992, art. 2107, 32 I.L.M. 605, 701 (1993).

Indeed, Canada hoped to avoid the entire litigation by reference to the NAFTA language, by which Canada assumed it exempted its domestic magazine industry from trade obligations. 
regulation have tended to provoke a host of unique political and social problems. $^{118}$

Since cultural industries embrace the dominant means of communication, their cultural significance is considerable. However, given the enormous profits at stake in Periodicals, cultural industries are, at the same time, competitive economic industries. ${ }^{119}$ Thus, had the AB analyzed Canada's domestic policy for legislative intent, it would have found both cultural and economic reasons supporting Bill C-103. Indeed, it is a symptom of globalizing trade that these two sets of concerns-cultural and economic-are increasingly inextricable from one another.

Thus, rather than assess the contribution of individual intellectuals, artists, writers, journalists, and musicians on a case-by-case basis, the government chose to protect Canadian culture by following an "infrastructural approach." ${ }^{120}$ Such a blanket approach, focused at the industry level, gives incentives to the particular industries sought to be protected. For example, Canada's "funded" postal rates for Canadian periodicals producers are just such an incentive. ${ }^{121}$

When cultural legislation implicates an entire industry, the motivations for that legislation are rightfully subjected to scrutiny. As U.S. Trade Representative Charlene Barshefsky observed, voicing her concern about the infrastructural approach: "We cannot allow Canadian entities to use 'culture' as an excuse to provide commercial advantages to Canadian products or to evict U.S. firms from the Canadian market."122 Indeed, from an industry perspective, it is not altogether surprising that the WTO regarded the Canadian periodicals industry no differently than it had the U.S. reformulated gasoline industry, ${ }^{123}$ or the Brazilian dried coconut industry ${ }^{124}$ - that is, as a competitive, economic market.

118 See, e.g., Bruce Stokes, Tinseltown Trade War, NAT'L J., Feb. 23, 1991, at 432, 433 (describing the dispute over inclusion of audiovisual services in the GATT and noting that "cultural industries are intrinsically different from manufacturing and pose unique political problems that defy normal trade rules").

119 See, e.g., de Fazekas, supra note 9, at 143 (arguing that cultural industries "are conceptually more economic than cultural").

120 Id. at 156 (defining the "infrastructural approach" as an alternative to a "case-by-case approach").

${ }^{121}$ See Periodicals AB Report, supra note 3, at *24 (discussing "funded" postal rates which, according to the $A B$, violate Article III:8(b) of the GATT).

${ }_{122}$ McDonald, supra note 54, at 54.

123 See generally GATT Dispute Panel Report on United States Standards for Reformulated and Conventional Gasoline, 2 Handbook of WTO/GATT Dispute Settlement, case 98, WTO Doc. WT/DS2/R, 1996, at 1023-44 (Jan. 29, 1996) (recommending that the United States modify its gasoline standards to meet its obligations under the GATT). 


\section{B. Toward a Workable Concept of the Cultural Product}

There is, nonetheless, something about a magazine that remains irreducible to the rigorous calculus of cross-price elasticity of demand-something profoundly unlike reformulated gasoline and dried coconut. Canadian Minister of International Trade Art Eggleton echoed this sentiment when he protested that a magazine "should not have been looked at ... like a widget." 125

How is a Canadian periodical different from a widget? Unlike widgets, gas, or coconut, Canadian periodicals are vehicles for Canadian cultural content, broadly understood as those expressions of " national heritage, $\mathrm{Ca}$ nadian cultural identity, stories about Canadians, their country, their way of life, and the issues that affect the way Canadians live."'126

Judging by its nullity before the WTO, cultural content seems to be suffering a crisis of representation. It would be concededly difficult, not to mention controversial, to build workable distinctions between products on the basis of their respective cultural content, however that term is defined. Similarly, the content distinctions argued by the Canadians were simply not registered by available GATT law or WTO dispute settlement. The proposition that such content should be adequately accounted for by international trade governance is the topic of an expanding corpus of literature. ${ }^{127}$

124 See generally GATT Dispute Panel Report on Brazil Measures Affecting Desiccated Coconut, 2 Handbook of WTO/GATT Dispute Settlement, case 101, WTO Doc. WT/DS22/R, at 1145-1228 (Oct. 17, 1996) (discussing issues surrounding duties imposed by Brazil on imported desiccated coconut from the Philippines).

125 McDonald, supra note 54, at 54.

126 de Fazekas, supra note 9, at 159 (quoting I D.C. CARD, CANADA-UNITED STATES Free TRADE AND CANADIAN CUlTURAL SOVEREIGNTY 87 (1987)). Perhaps significantly, Card regards these criteria as "quantifiable and objective." Id. (quoting $1 \mathrm{CARD}$, supra, at 21-47). To think of an example other than Maclean's in Canada, one might consider how the prose of Gabriel García Márquez captures the culture of the Caribbean coast of Colombia in a way not likely to be confused with Charles Dickens's accounts of English working-class culture during the Industrial Revolution. Compare GABRIEL GARCIA MÁRQUEZ, CEEN AÑoS DE SOLEDAD (cuarta edición 1983) (1967), with CHARLES DICKENS, GREAT EXPECTATIONS (Margeret Cardwell ed., Oxford Univ. Press 1994) (1861). In either case, there is an expression-though not necessarily one that is susceptible to empirical inquiry-of the culture from which the work was produced, and about which it is a commentary.

${ }^{127}$ See, e.g., Philip M. Nichols, Trade Without Values, 90 Nw. U. L. REV. 658, 660 (1996) (arguing that the WTO "fails to take into account the fundamental nature of societal values, and creates little or no space in which such laws can exist" and that "[t]his intemperance may diminish the already fragile support for the international trade regime, which in turn may hinder the ability of member countries to support the World Trade Organization"); W. Ming Shao, Is There No Business Like Show Business? Free Trade and Cultural Protectionism, 20 YALE J. INT'L L. 105, 115 (1995) ('[C]ulture possesses certain values that are inherently opposed to, and threatened by, commercial forces[] the need for these values is universal[,] and $[$ the market cannot satisfy this need."). 
What remains to be considered is how this crisis of representation might have otherwise been resolved within the existing GATT/WTO regime. Canada needed a concept that could mediate its legitimate interest in ensuring Canadian cultural content with the WTO's increasingly rigid, rule-based enforcement of GATT obligations. In other words, Canada needed to translate this interest into a concept recognizable by a panel of international trade experts.

The "public good" is the mediating concept. The Canadians' submission to the Panel noted that the intellectual content of a magazine, although "delivered to consumers in the form of a private good," is itself a public good. ${ }^{128}$ But the Canadians scarcely developed the public good concept, perhaps because the source from which they extracted it—a 1995 article by W. Ming Shao-ultimately concluded that protectionism of the type practiced in Ottawa could only offer "dubious cultural benefits at the expense of undermining the GATT."129 It nonetheless bears asking whether a concept of the public good might help in distinguishing certain products, and therefore in elaborating a workable definition of the "cultural product" (the category of products to which the amendment proposed by this Comment in the next Subpart will apply).

First, public goods are non-rival in consumption, meaning that the cost of adding the marginal consumer will be "zero or close to zero."130 This is generally true of magazines, because their content-words, photography, and so on-is easily duplicated at little cost. Conversely, gas and coconut cannot be easily duplicated at little cost. The electronic split-run technology, which enabled Time Warner to circumvent the Canadian import prohibition, ${ }^{131}$ best exemplifies the non-rival characteristic of a magazine's intellectual content, because it makes the content available to an increasingly greater number of consumers at a declining marginal cost. Beamed into Canada, the magazine is multiplied for pennies a copy.

${ }^{128}$ First Written Submission of Canada Submitted to the Panel Established by the Dispute Settlement Body of the World Trade Organization to Examine Three Canadian Measures Concerning Periodicals, June 9, 1997, available in 19XX WL 213177, at *3 (W.T.O.) (discussing the distinctive qualities of magazines). The Canadian submission relies on principles developed in the context of trade in audiovisual goods and services. See Shao, supra note 127 , at 119 (discussing audiovisual goods and services as public goods).

129 Shao, supra note 127 , at 150.

130 Id. at 120.

131 See supra notes 51-60 and accompanying text (discussing electronic split-runs). 
Second, public goods are non-excludable, meaning that their consumption by others is nearly impossible to prevent. ${ }^{132}$ For example, the public good of national defense is a non-excludable good, because one cannot provide it to a neighbor without at the same time providing it to oneself. Magazines, however, are excludable goods in that they are embodied in a tangible, physical form. Like gas and coconut in this respect, magazines are delivered to the consumer as a commodity. Other cultural products, such as videos, compact discs, and paperback books, share this form, exhibiting the characteristics of non-rivalness and excludability. Thus, W. Ming Shao could conclude that cultural products are generally hybrid in construction"[t]heir content is a public good, but they are [often] delivered to customers in the form of a private good." 133 Shao's terminology suggests a workable definition of cultural products: those products that are simultaneously nonrival (hence, public) and excludable (hence, private), and whose content is in some minimal sense "cultural." "134 The definition recognizes a difference between magazines, gas, and coconut, and characterizes only the first in this series as a cultural product.

\section{An Amendment for Cultural Products}

Given the benefit of hindsight and armed with Shao's definition, one can appreciate the uncomfortable posture of the cultural product within an economic framework clearly designed for more mundane, less-politicized commerce. Thus, it should be of little surprise that the theory of comparative advantage, ${ }^{135}$ from which the most strident proponents of free trade rightfully draw intellectual sustenance, also cannot adequately account for the cultural product. On one side, inefficient producers of such products are still motivated to produce them, despite economic loss; on the other, price is not always the determinative factor in a consumer's purchasing decision. ${ }^{136}$

132 See Shao, supra note 127 , at 120 ("Non-excludability means that consumption of a good is impossible to exclude, or if exclusion is technically feasible, that it is too expensive to apply."). (1992))

Id. (quoting BRUCE M. OWEN \& STEVEN S. WILDMAN, VIDEO ECONOMICS 23

${ }^{134}$ For a suggested definition of "cultural content," see supra note 126 and accompanying text.

${ }^{135}$ The theory of comparative advantage holds that free trade encourages nations to produce that which they have a natural advantage in producing, either by virtue of natural resources, particular skills, technologies, and so on. See, e.g., DOUGLAS A. IRWIN, AGAINST THE TIDE: AN INTELLECTUAL HISTORY OF FREE TRADE 51 (1996) (discussing the theory of comparative advantage).

${ }^{36}$ See Braun \& Parker, supra note 39, at 174 (explaining that cultural products do not fit well within the theory of comparative advantage). 
Given the incongruency between a trading regime and the theory on which it is based, it would seem reasonable to treat cultural products differently than noncultural products.

Further, if one takes the view that a state's first obligation is to provide public goods for its citizens, ${ }^{137}$ then Canada's inability to do so in this case is likely to result in an insufficiency of such goods for Canadian consumption. The displacement of Canadian cultural content from the postPeriodicals newsstand can then be characterized as a negative externality. As Shao explained, "Externalities occur when the market price of a good or service does not reflect all the benefits and costs associated with its production and consumption." 138 The presence of significant externalities indicates market failure, which often justifies alternative allocations of goods and services. ${ }^{139}$

Admittedly, resorting to a theory of market failure implies some defect in the Canadian consumer's penchant for the U.S. magazine over its domestic rivals-a lack of information, and therefore an inability to fully appreciate the consequences of her substitution of the former for the latter. The shortsightedness of the domestic consumer of imported cultural products is nonetheless a symptom of trade globalization, or, more generally, of what cultural critic Fredric Jameson calls the destruction of the "semi autonomy of the cultural sphere" by the logic of late capitalism. ${ }^{140}$ Trade globalization has tended to convert formerly political decisions-for instance, on the desirability of maintaining a domestic cultural infrastructure-into narrowly economic ones. ${ }^{141}$ This is so despite a lack of evidence to suggest, for ex-

137 See MANCUR Olson, The LOGIC OF COLlective ACTION: PUBlic GoOdS AND the THEORY OF GROUPS 15 (1971) ("A state is first of all an organization that provides public goods for its members, the citizens....").

138 Shao, supra note 127, at 137.

139 See id. ("Market failure can result and may justify nonmarket allocation of these goods and services.").

140 JAMESON, supra note 2, at 87.

141 Of the dozens of articulations of the concept of the externality, economist James Meade best captures this tendency as it applies in Periodicals. Meade explained that "[a]n external economy (diseconomy) is an event which confers an appreciable benefit (inflicts an appreciable damage) on some person or persons who were not fully consenting parties in reaching the decision or decisions which led directly or indirectly to the event in question." JAMES E. MEADE, THE THEORY OF ECONOMIC EXTERNALITIES: THE CONTROL OF ENVIRONMENTAL POLLUTION AND SIMLAR COSTS 15 (1973).

In Periodicals, Meade's concept of the externality suggests that by placing into direct competition domestic and split-run magazines, an appreciable damage is inflicted on the Canadian consumer. The consumer, in turn, is not a fully consenting party in the sense that the lower price for which she can now acquire the split-run magazine does not fully compensate her for the loss of particular intellectual content, cultural identity, a Canadian perspective, and so on. That such content is valued by the Canadian consumer was established by a recent 
ample, that the drafting of Article III was motivated by any such intention. ${ }^{142}$ Assuming that even a small diversion of Canadian advertising revenues to U.S. split-runs will be ruinous for the Canadian magazine industry, ${ }^{143}$ and that the consumer's purchasing decision determines not only the industry's profitability but its very viability, then the consumer's myopia seems particuiarly suited to an alternative allocation.

What type of alternative allocation might best address the problems we have been tracking? Because GATT Article III:2 permits a national treatment claim to be established under either the "like products" or the "directly competitive" clause, the categorization of a product as a cultural product is unlikely to be of much utility to the party arguing for its relevance. For instance, even if Canada had established that the domestic and split-run magazines were not "like," it could not have escaped the AB's conclusion that the magazines were, nonetheless, "directly competitive." 144 Hence, the broad "directly competitive" clause is likely to render immaterial the subtle, more searching analysis of the "like products" inquiry.

Based on Shao's articulation of the cultural product, this Comment proposes the following substantive amendment to GATT Article III:2:

Where a dispute concerns a cultural product, however, the complaining Member will be required to establish violations under both the first sentence ("like products" clause) and the second sentence ("directly competitive" clause) of Article III: 2 in order to justify a finding in its favor.

Under such an amended provision, the United States would not have prevailed upon the simple showing that the magazines in question compete for the same advertising markets, making them "directly competitive." Instead, the United States would have been required to prove that imported split-run and domestic magazines are "like products"-a case it may well have lost to Canada.

poll, in which $84 \%$ of those polled thought it "important to them to read Canadian stories." Schofield, supra note 6 , at 45 .

142 See supra notes 26-28 and accompanying text (noting that the term "like products" in Article III was never defined).

${ }^{143}$ See supra notes 54-60 and accompanying text (discussing the impact of Canadian advertising in American split-runs on the Canadian magazine industry).

144 Indeed, it is hard to imagine a case where the "like products" analysis would be necessary to establish a national treatment violation. GATT doctrine suggests one such scenario, as the "directly competitive or substitutable" clause allows for an exception in the case of internal taxes imposed by local governments which would suffer "serious financial hardship" upon the repeal of such taxes. See GATT, supra note 4, art. III, ๆ 1. But such an isolated example would hardly seem to justify the rather deliberately worded first sentence of article III:2. 
The equity in such a proposal is that it would permit U.S. producers to compete with Canadian producers for the production and sale of Canadian content. Thus, Time Warner would have been welcome to compete with Maclean's in Canada by producing its own version of a Canadian news magazine, which, if it passed a narrow "like products" analysis, would be free from discriminatory taxation. The "like products" analysis would apply the Border Tax factors, comparing the two versions in terms of end-use, intellectual content, subject matter, perspective, consumer perception, and so on. $^{145}$

Clearly the proposed amendment would be less attractive for U.S. producers because it eliminates the economic advantages of the electronic splitrun. Time Warner would incur the cost of producing content, for which it would compete with Maclean's. For that very reason, the proposal more faithfully reflects the theory of comparative advantage on which free trade is premised: Canadian magazine producers should enjoy a comparative advantage in the production of Canadian content, to which they have comparatively greater access and familiarity. In reality, they always have enjoyed this advantage, which is why Time Warner has never challenged them on that front.

As for the real impact of the proposed amendment, it is not clear how many "cultural products" would seek the elevated protection of a "like products" analysis. Audiovisual trade, for example, was exempted from the GATT during the most recent negotiations (on the insistence of the European Union, led by the French). ${ }^{146}$ Many other cultural products, meanwhile, might more plausibly be covered under other agreements. For example, a theater production might come within the General Agreement on Trade in Services, ${ }^{147}$ while the intellectual content of a jazz recording would be covered by the agreement on Trade-Related Aspects of Intellectual Property Rights. ${ }^{148}$

145 See Border Tax, supra note 29 and accompanying text (recommending a case-by-case consideration of "like products").

${ }^{146}$ See, e.g., Chao, supra note 53, at 1129 (discussing the Uruguay Round Negotiations on the audiovisual trade).

${ }^{147}$ See generally General Agreement on Tariffs and Trade-Multilateral Trade Negotiations (The Uruguay Round): General Agreement on Trade in Services, Dec. 15, 1993, 33 I.L.M. 44 (1994) (establishing the nature and scope of international obligations regarding trade in services).

148 See generally Agreement on Trade-Related Aspects of Intellectual Property Rights, Apr. 15, 1994, Marrakesh Agreement Establishing the World Trade Organization, Annex 1C, art. 16, LEGAL INSTRUMENTS-RESULTS OF THE URUGUAY ROUND vol. 31; 33 I.L.M. 81 (1994) (establishing the nature and scope of international obligations regarding intellectual property). 
Nonetheless, there is some merit in developing the concept of the cultural product as a countermeasure to the rigidity of WTO dispute resolution and the externalities it produces. The cyclical revolutions in information technology assure that new products and services will always outpace our capacity to imagine them beforehand, much less draft trade agreements that predict their multitudinous effects. Cultural products could either be exempted from trade agreements, as in Canada's NAFTA exemption; covered by more specific agreements, as in the preceding paragraph; or, as this Comment has proposed, permitted the shelter of a narrow "like products" analysis.

\section{CONCLUSION}

The WTO Panel and AB decisions in Periodicals present many contradictions in the struggle between cultural identity and liberalized free trade. Although Canada has long protected its cultural industries from competition by U.S. producers, the electronic transmission of editorial content into Canada has successfully challenged these policies. At one time, however briefly, GATT panels indicated a willingness and a capacity to consider domestic policy objectives in the litigation of Article III disputes. The fledgling WTO has clearly renounced this approach. In Periodicals, Canada's arguments on the incomparability of domestic and split-run contents was given no weight.

As a hybrid cultural product, the magazine shares qualities of both public and private goods. When the nation-state's ability to encourage and ensure the production of cultural products is eliminated by trade agreements, the need for a particular public good goes unfulfilled. By excluding magazines like Maclean's from the newsstand, the post-Periodicals liberalization of the magazine trade will produce certain negative externalities in Canada. Among these is the disappearance of a Canadian perspective, a development that threatens Canadian identity and closes avenues of cultural expression. These externalities, in turn, undermine the political acceptability of the WTO among the domestic constituencies they affect.

In order for the global trade regime to register the complexity of cultural products, this Comment proposes an amendment to Article III:2 of the GATT. The amendment would ensure that legislation protecting cultural products would be sheltered by a narrow, case-by-case "like products" inquiry before any panel finds impairment of GATT obligations. Nations wishing to protect certain cultural products from the pressures of international competition would be allowed to articulate, by application of the Border Tax factors, distinctions between its domestic cultural product and competing imported cultural products. The hope is that some domestic cultural 
production-and, thereby, a forum for the manifold, residual cultures against which an increasingly dominant one exerts its market influencemight be salvaged in the wake of the flood. 